\title{
COMMENTARY: BIRD RECORDS IN SASKATCHEWAN AND THE BLUE JAY
}

\author{
PAUL C. JAMES and BOB KREBA, Saskatchewan Museum of Natural History, \\ 2340 Albert Street, Regina, Saskatchewan. S4P 3V7, and ALAN R. SMITH,
} Canadian Wildlife Service, 115 Perimeter Road, Saskatoon, Saskatchewan. S7N 0X4

With the recent publication of the latest checklist of Saskatchewan birds, ${ }^{12}$ we felt it was timely to record some concerns that we have with respect to the reporting of bird records in the province.

The checklist clearly states that unless confirmed by either a specimen or an identifiable photograph, a species remains hypothetical. However, a review of bird records published in the Blue Jay for 1989 and 1990 give the reader a quite different impression.

It is not unusual to come across titles of articles that indicate the positive recording and identification of new or hypothetical species without the required supporting evidence. $2,3,4,5,6,7,10,11,15$ This contrasts with similar titles of articles in which records have been substantiated. ${ }^{1,2,8,9,13}$ This, in itself, would not be a significant problem if the articles were always available and read. However, they are not. The Blue Jay is a regional journal that is distributed worldwide, and more importantly, is abstracted by leading indices such as Recent Ornithological Literature and Zoological Record. These publications record only the title of the article; the researchers compiling species' records will likely take them at their face value. This, we believe, will lead to the further reporting of records that lack substantiating evidence to the ultimate discredit of both the Blue Jay and the Saskatchewan Natural History Society.
To avoid this situation, we suggest that the titles of articles reporting bird records without the required evidence should carry prefixes such as "possible" or "sight." This would not only indicate the true nature of the evidence, but would also not discourage the reporting of such observations by field observers.

Furthermore, we believe that the acceptance of species to the Saskatchewan hypothetical list is presently far too easy. This has resulted in a burgeoning proportion (currently 12\%) of Saskatchewan's avifauna being of questionable status. This compares with only $4 \%$ of Alberta's checklist. ${ }^{14} \mathrm{We}$, therefore, suggest that a records committee be formed to not only review new records but also the entire hypothetical list. Such a committee would accept or reject records on the basis of evidence alone, ultimately leading to improved standards of field reporting in the province.

1. BARR, K. 1990. House Finch at Regina, Saskatchewan. Blue Jay 48:167.

2. BJORKLUND, C.G. 1990. Bromhead rare bird records. Blue Jay 48:212-217.

3. BRAZIER, F.H. 1989. Kentucky Warbler singing in Regina. Blue Jay 47:152.

4. 1989. Ivory Gull in Regina. Blue Jay $47: 153$

5. 1989. Laughing Gull in Regina. Blue Jay $47: 157$.

6. — 1989. White-eyed Vireo - first for 
Saskatchewan. Blue Jay 47:216.

7. - 1990. Olivaceous Cormorant - first record for Canada. Blue Jay 48:154-155.

8. CHYTYK, P. 1990. Saskatchewan's first Black-legged Kittiwake. Blue Jay 48:112-114.

9. DECHKA, S.S. 1990. Saskatchewan's first Garganey observations. Blue Jay $48: 320$.

10. HOLMES. P.M. 1990. Scissor-tailed Flycatcher at Eastend, Saskatchewan. Blue Jay 48:221.

11.HOOPER, D.F. 1990. House Finch and American Woodcock at Somme,
Saskatchewan. Blue Jay 48: 47-48.

12. KREBA, R. 1990. Field checklist of Saskatchewan birds. Sask. Mus. Nat. Hist.

13. LAWRENCE, F. 1990. Prothonotary Warbler in Regina. Blue Jay 48:45-46.

14. STEPNEY, P. H. R. 1981. Checklist of Albertan birds. Provincial Museum of Alberta.

15. WEDGWOOD, J. 1990. Ross' Gull near Saskatoon, Saskatchewan. Blue Jay 48:158-161.

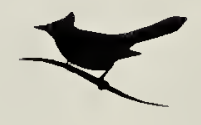

\section{Christmas Bird Count Update - Val Marie, Saskatchewan}

The following count was received too late for inclusion in the compiled results. The count was carried out on 16 December 1990 . Temperature $-20^{\circ}$ to $-10^{\circ} \mathrm{C}$, wind light, snow cover was $5-10 \mathrm{~cm}$, overcast with light snow in morning, sunny in afternoon. In total, 13.5 hours were spent covering $148 \mathrm{~km}$ by vehicle and $12 \mathrm{~km}$ on foot.

Bald Eagle, 1; Northern Goshawk, 1; Rough-legged Hawk, 1; Golden Eagle, 3; Gray Partridge, 12; Ring-necked Pheasant, 82; Sharp-tailed Grouse, 5; Rock Dove, 1; Great Horned Owl, 4; Short-eared Owl, 2; Horned Lark, 125; Black-billed Magpie, 82; Northern Shrike, 2; Snow Bunting, 1,117; Evening Grosbeak, 1; House Sparrow, 186. 16 species, 1,625 individuals.

Observers: Lynn Grant, Allan Hall, Don McDonald, Cheryl Penny, Lise Perrault, Jacques Saquet. 